\title{
ANDRAGOŠKA DEDIŠČINA SABINE JELENC KRAŠOVEC
}

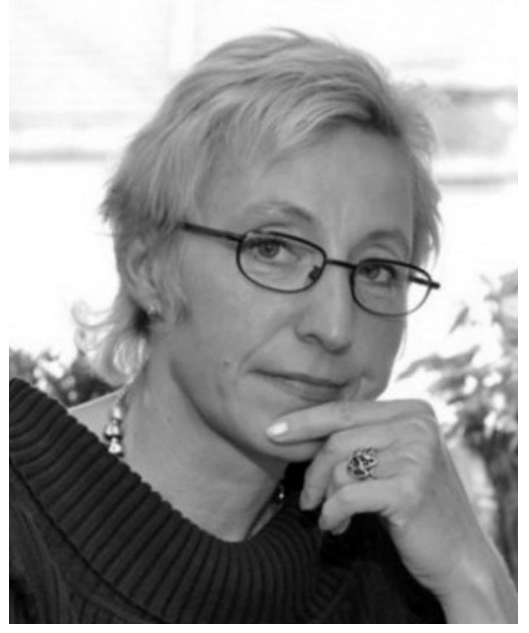

Mnogo prezgodaj, dober mesec pred 53. rojstnim dnem, se je konec preteklega leta iztekla življenjska pot naše prijateljice in sodelavke, izr. prof. dr. Sabine Jelenc Krašovec. Težko je na kratko predstaviti pestro, bogato in raznovrstno izobraževalno, znanstveno, raziskovalno, strokovno in pedagoško delo Sabine na področju izobraževanja odraslih, kljub temu bom v nadaljevanju poskušala povzeti ključne mejnike in dosežke na njeni poklicni poti.

Rojena je bila 26. januarja 1968 v Ljubljani. Po končani Srednji pedagoški šoli je leta 1986 nadaljevala študij na Filozofski fakulteti - domska in andragoška smer (A) in smer sociologija (B). Med študijem je kot prostovoljna svetovalka ministrstva za pravosodje individualno svetovala in pomagala obsojencem. Decembra 1991 je na Oddelku za sociologijo - smer sociologija (B) diplomirala s temo Beg možganov, februarja 1992 pa je na Oddelku za pedagogiko - smer pedagogika (A) z odlično oceno zaključila študij z diplomsko nalogo Pismenost in funkcionalna pismenost obsojencev $v$ Sloveniji. Podiplomski študij je na isti fakulteti leta 1998 zaključila z zagovorom magistrske naloge s področja andragogike z naslovom Trendi razvoja andragoške teorije in prakse v Evropi - Vloga izobraževanja odraslih pri razvijanju dejavne državljanskosti v prehodnem obdobju, leta 2000 pa še z uspešnim zagovorom doktorske disertacije Univerza v procesih oblikovanja učeče se družbe. Dodatno se je izobraževala $v$ okviru številnih seminarjev na področju andragoške in visokošolske didaktike, usposabljala se je za svetovanje in ocenjevanje predhodno pridobljenega znanja v procesu ugotavljanja in potrjevanja znanja, med drugim je pridobila naziv »Change Agent « - NLP. V okviru rednega šolanja se je učila dva tuja jezika: angleščino in nemščino. Znanje angleškega jezika je dodatno izpopolnjevala julija 1988 v Veliki Britaniji (Anglo World Education, Oxford) in od junija do septembra 1990 v Združenih državah Amerike (Springfield, MA), kjer je v poletnih taborih za revne otroke pridobila dragocene delovne in življenjske izkušnje. Poleg rednega šolanja je končala nižjo glasbeno šolo in dodatna dva razreda za klavir (osem razredov) in kitaro (devet razredov). Več let je igrala v kitarskem orkestru Glasbene šole Franca Šturma. 
Sabina je svojo profesionalno pot začela leta 1992 kot pripravnica na Andragoškem centru Slovenije, od oktobra 1993 dalje pa je bila redno zaposlena na Filozofski fakulteti Univerze v Ljubljani - Oddelek za pedagogiko in andragogiko, najprej kot asistentka, kasneje kot docentka in nazadnje kot izredna profesorica. Odlikovala jo je bogata in uspešna pedagoška dejavnost. V okviru dodiplomskega študija je bila nosilka predmetov Andragogika ciljnih skupin, Andragoško svetovalno delo in soizvajalka predmeta Sociologija izobraževanja odraslih, na podiplomskem študiju pa nosilka predmeta Andragoški raziskovalni seminar in Andragogika ciljnih skupin ter soizvajalka predmeta Izbrane teme iz sociologije izobraževanja odraslih. Pri predmetu Andragoško svetovalno delo in Andragogika ciljnih skupin je izvajala dodatne individualne konzultacije Erasmus-Socrates študentom iz Litve, Nemčije, Finske, Poljske, Estonije, Grčije itd. Bila je izredno predana in zavzeta pri delu s študenti, kar med drugim dokazuje dolg seznam (122) njenih mentorstev. Kot ocenjevalka je sodelovala v komisijah za oceno magistrskih nalog na Pedagoški fakulteti Univerze na Malti. V okviru Centra za pedagoško izobraževanje Filozofske fakultete Univerze $\mathrm{v}$ Ljubljani je kot predavateljica sodelovala tudi v programu pedagoško-andragoškega izobraževanja za predavatelje višjih strokovnih šol. Njen naravni dar za poučevanje dokazuje svečana listina Univerze v Ljubljani, ki jo je kmalu po začetku akademske kariere prejela za izjemne pedagoške in raziskovalne dosežke.

Študenti, ki jih je pretresla vest o prezgodnjem odhodu Sabine, so sporočali, da jo bodo ohranili v najlepšem spominu z globoko hvaležnostjo in občudovanjem, saj jih je s svojim entuziazmom navdihovala in spodbujala $\mathrm{k}$ samostojnemu in kritičnemu mišljenju, $\mathrm{v}$ njih je prebujala radovednost do raziskovanja, skrb za ranljivejše in pogum za zavzemanje za pravičnejši svet. Na spletu sem našla tudi starejše pohvalne izjave njenih nekdanjih študentov. Tako je ena od študentk pred leti zapisala: »Najboljša profesorica, kar sem jih kdaj imela! Profesorica Jelenc Krašovec več kot očitno tudi živi, udejanja to, kar predava. Meni je prav v navdih. Da človek razmišlja s svojo glavo, spreminja sebe in posledično tudi družbo. Profesorica, ki se zaveda, da več kot neki uradni nazivi pomeni to, kakšen si kot človek, tvoja morala, vrednote in tvoj odnos do drugih. Študente nagovarja kot sebi enake, je zelo pozitivna, ima veliko znanja, odprta. Mnogi profesorji bi se lahko zgledovali po njej.«

Z Andragoškim centrom Slovenije je kot predavateljica in vodja številnih delavnic ter seminarjev vsa leta svojega profesionalnega delovanja redno sodelovala v različnih programih izobraževanja za učitelje odraslih in druge strokovnjake, ki sodelujejo v izobraževanju odraslih. Med drugim je sodelovala pri pripravi gradiv, razvoju in izvajanju programov Usposabljanje za življenjsko uspešnost, Usposabljanje vodij in mentorjev študijskih krožkov, Izobraževanje in usposabljanje svetovalcev in ocenjevalcev predhodno pridobljenih znanj in spretnosti, Phare program UNDP Mine Action Senior and Middle Management Training Course in programu Izobraževanje tutorjev v projektu Študij na daljavo. Sodelovala je tudi pri pripravi programa $»$ Razvijanje in širjenje mreže z IKT podprtih lokalnih svetovalnih centrov in centrov za poklicno svetovanje ter točk za VŽU « v okviru projekta ESS. Poleg tega je bila tudi svetovalka in ocenjevalka v procesu »Ugotavljanja 
in potrjevanja predhodno pridobljenih znanj in spretnosti«. Ob njeni prezgodnji smrti so se na Andragoškem centru Slovenije spomnili, da je po odhodu na Filozofsko fakulteto za vedno ostala njihova dragocena zunanja sodelavka $v$ različnih projektih in dejavnostih centra, bila je nepogrešljiva in zelo dobro sprejeta predavateljica v programih andragoškega spopolnjevanja.

Toda Sabina ni bila samo odlična profesorica in predavateljica, ampak je bila tudi strastna raziskovalka. Sociološka izobrazba ji je zagotavljala široka teoretska znanja, s katerimi je izobraževanje odraslih vedno osmišljala v družbenem kontekstu. Bila je prepričana, da če želimo razumeti izobraževanje odraslih, je to mogoče le s kritično analizo političnih, ekonomskih in družbenih vidikov njegove strukture. V večini svojih besedil je izhajala iz družbeno kritične vloge izobraževanja odraslih in poudarjala emancipatorni potencial andragogike, razmišljala je o mobilizacijski vlogi andragogike v širšem družbenem kontekstu, predvsem kako lahko andragogika vpliva na družbene spremembe. Rdeča nit njenih besedil je bila kritična teorija družbe ter kritična in radikalna tradicija izobraževanja odraslih. Tako je v članku o izobraževanju za pismenost v luči kritične teorije izobraževanja odraslih poudarila: »Nizka udeležba nekaterih skupin prebivalstva v izobraževanju je zlasti posledica izključevalnih družbenih praks (tudi izobraževanja), ki so tesno povezane z ideologijami moči, interesi kapitala, krepitvijo individualizma ter zmanjševanjem socialne skrbi s strani države. «Zavedala se je, da mnogi področje izobraževanja odraslih pojmujejo kot področje praktičnega delovanja, zato je opozarjala, da ga ni mogoče razvijati brez ustrezne refleksije in teoretskih podlag. Ob tem je zapisala: »Vendar pa ravno praksa izobraževanja odraslih kaže, da so razmerja moči (pri določanju ciljev, načrtovanju programov, načinih poučevanja idr.) tista ključna sestavina, ki pomembno vpliva na ohranjanje družbene neenakosti in nepravičnosti. Praktiki se ukvarjajo zlasti z vprašanji, kako motivirati obrobne skupine za izobraževanje, kakšne metode uporabljati pri delu z njimi ipd., medtem ko se o vzrokih izključenosti skorajda ne razpravlja.«

$\mathrm{V}$ njenem obsežnem znanstvenoraziskovalnem opusu lahko odkrijemo zelo raznolike teme proučevanja področja izobraževanja odraslih, med njimi: pismenost odraslih, vlogo andragoga, izobraževanje starejših, izobraževanje starejših zaposlenih, javne prostore kot prizorišča priložnostnega učenja odraslih, transformativno učenje, splošno izobraževanje odraslih, politiko izobraževanja odraslih, ciljne ranljive skupine odraslih, medgeneracijsko učenje, svetovalno dejavnost, dejavno državljanstvo, vseživljenjsko izobraževanje na univerzi, javno andragogiko itd.

Kot raziskovalka je Sabina sodelovala v sedmih mednarodnih projektih: »Delphi - The Future of Adult Education in Europe«, »Phare MOCCA - Modernisation of Curricula, Certification and Assessment«, »Vocational Education for Youth and Adults in Slovenia «, »National Guidance Policy Forums - Developing National Fora for Guidance in Six Member States - Malta, Estonia, Denmark, Slovenia, the United Kingdom and Ireland « in kot vabljena izvedenka v projektu Grundtvig »Right to Learn«. Sodelovala je tudi v obsežnem mednarodnem projektu PIAAC o spretnostih odraslih, v katerem je proučevala izobraževanje in učenje starejših delavcev. Do konca leta 2014 je tri leta koordinirala 
mednarodni projekt LLL Grundtvig Partnership z naslovom »Older Men as Active Learners in Community (OMAL)«. V okviru naštetih projektov je še posebej intenzivno sodelovala z raziskovalci z univerz na Malti, Portugalskem, Irskem, Poljskem, v Srbiji, Estoniji, Avstraliji, Novi Zelandiji in Veliki Britaniji. Bila je tudi gostujoča profesorica na Univerzi v Vroclavu.

V okviru Fakultete za družbene vede je od leta 2004 do 2008 raziskovalno delovala v programski skupini »Kakovost življenja družbenih skupin« in v treh temeljnih raziskovalnih projektih: »Socialna integracija starostnikov v Sloveniji« (2004-2007), »Medgeneracijska solidarnost v Sloveniji« (2009-2012) in »Oskrba starejših v skupnosti v Sloveniji« (2011-2014). V vseh treh raziskavah je bila njena pozornost namenjena učenju in izobraževanju starejših v različnih kontekstih. Od leta 2009 dalje je bila na Filozofski fakulteti kot raziskovalka vključena najprej v programsko skupino »Pedagoške in andragoške raziskave - konceptualizacija znanja za trajnostni razvoj, razvoj človeških virov in socialno kohezivno družbo«, kasneje pa še v programsko skupino »Pedagoško-andragoške raziskave - Učenje in izobraževanje za kakovostno življenje v skupnosti«.

Rezultate svojega raziskovalnega dela je predstavila na številnih mednarodnih in domačih konferencah, prav tako pa jih je objavljala tudi v mnogih uglednih znanstvenih revijah in monografijah. Njen znanstvenoraziskovalni, pedagoški in strokovni opus je zelo obsežen, kar je razvidno tudi iz njene bibliografije, saj ima v slovenskem knjižničnem informacijskem sistemu COBISS vpisanih 441 bibliografskih enot.

Sabina je bila tudi aktivna članica uredniških odborov štirih znanstvenih revij, to so Andragoška spoznanja (zadnja leta tudi sourednica), Andragoške studije, Sodobna pedagogika in The European Journal for Research on the Education and Learning of Adults (RELA). $\mathrm{V}$ vlogi urednice je sodelovala $\mathrm{v}$ pripravah mednarodnih znanstvenih monografij.

Dejavna je bila tudi v različnih strokovnih telesih: bila je predsednica komisije za druge javno veljavne izobraževalne programe za odrasle in članica komisije za obravnavo strateških vprašanj pri Strokovnem svetu RS za izobraževanje odraslih, članica strokovnega sveta Andragoškega centra Slovenije, članica akademskega zbora Filozofske fakultete, članica izvršnega odbora Andragoškega društva Slovenije in članica področne strokovne skupine za izobraževanje odraslih pri pripravi Bele knjige o vzgoji in izobraževanju v Republiki Sloveniji 2011. Tudi njena društvena dejavnost je bila raznolika. Bila je aktivna članica Andragoškega društva Slovenije, Sociološkega društva Slovenije in European Society for Research on the Education of Adults (ESREA).

Prevzemala je vodstvene naloge in bila najprej namestnica, pozneje predstojnica Oddelka za pedagogiko in andragogiko, predstojnica andragoške katedre ter vodja raziskovalnega programa »Pedagoško-andragoške raziskave: Učenje in izobraževanje za kakovostno življenje v skupnosti« v okviru Znanstvenega inštituta Filozofske fakultete.

V preteklih letih je aktivno sodelovala na Pedagoško-andragoških dnevih Filozofske fakultete, posvetih Andragoškega društva Slovenije, Andragoških kolokvijih v okviru 
Tedna vseživljenjskega učenja, Andragoških poletnih šolah v Ajdovščini, Festivalih za tretje življenjsko obdobje in mnogih drugih znanstvenih kongresih doma in v tujini. Od leta 1995 je bila kot organizatorka konferenc in članica znanstvenih odborov konferenc aktivna v Evropskem društvu za raziskovanje izobraževanja odraslih - ESREA in njegovih raziskovalnih mrežah. Leta 2012 je Sabina v okviru Filozofske fakultete Univerze v Ljubljani ter v sodelovanju z ESREA in CMEPIUS v Ljubljani organizirala in koordinirala mednarodno konferenco ESREA raziskovalne mreže »Education and Learning of Older Adults « (ELOA) z naslovom »Intergenerational solidarity and older adults education in community«, leta 2015 pa še uspešno mednarodno konferenco ESREA raziskovalne mreže »Between Global and Local: Adult Learning and Development « z naslovom »Perspectives on community practices: living and learning in community«.

S Sabino sem se zbližala v času, ko sem prevzela mentorstvo za njen doktorat. Bila je kritična, radovedna, svobodomiselna, ustvarjalna in aktivna državljanka, a hkrati topla in pozorna. Nepozabni spomini me vežejo na najino skupno pedagoško in raziskovalno delo, ko sva občasne zagate premagovali s smehom in samoironijo, kar pa nama je dajalo nov zagon po obdobjih, ko sva bili v dvomih in ko je najino delo zastalo. Zelo sem uživala $\mathrm{v}$ najinem druženju. Sabina je bila dragocena, zvesta prijateljica. Po moji upokojitvi se je najino sodelovanje sicer skrčilo, toda še vedno sva se družili, prijateljevali, še naprej mi je redno pošiljala razglednice z izletov, strokovnih potovanj in dopustov. Na eni zadnjih kartic je zapisala: »Širina pogledov na življenje pomaga pri premagovanju težav. Srečno in naj najine poti ostanejo prepletene. Še na mnoga srečanja, na prijateljstvo za vedno!« $\mathrm{V}$ treh letih boja s težko boleznijo je ostajala pozitivna in pogumna. Izgubila sem drago prijateljico, tesno sodelavko in svojo mentoriranko, ki mi je bila v mnogočem navdih.

S svojim poznavanjem, zavzetostjo in angažiranostjo je Sabina dala neizbrisen pečat področju izobraževanja odraslih na Slovenskem. Njena zapuščina bo za vedno zaznamovala andragoško stroko. Sabinina besedila bodo tudi v prihodnje ostala kot močni impulzi in navdih za razvoj nadaljnjih teoretičnih in empiričnih raziskav o izobraževanju odraslih, še zlasti na področju izobraževanja ranljivih ciljnih skupin, izobraževanja in učenja starejših, medgeneracijskega učenja, transformativnega učenja, učenja odraslih v skupnosti in na javnih prostorih. Verjamem, da bodo nove generacije andragogov in andragoginj sledile njenim idejam o prizadevanju za skupno, javno dobro in pravičnejši, boljši svet. 